\title{
Coloured tail-coverts in Anser $\times$ Branta goose hybrids despite all- white coverts in both parent species
}

\author{
Färgade stjärttäckare hos Anser $\times$ Branta gåshybrider trots helvita täckare hos \\ båda föräldraarterna
}

C. G. GUSTAVSSON

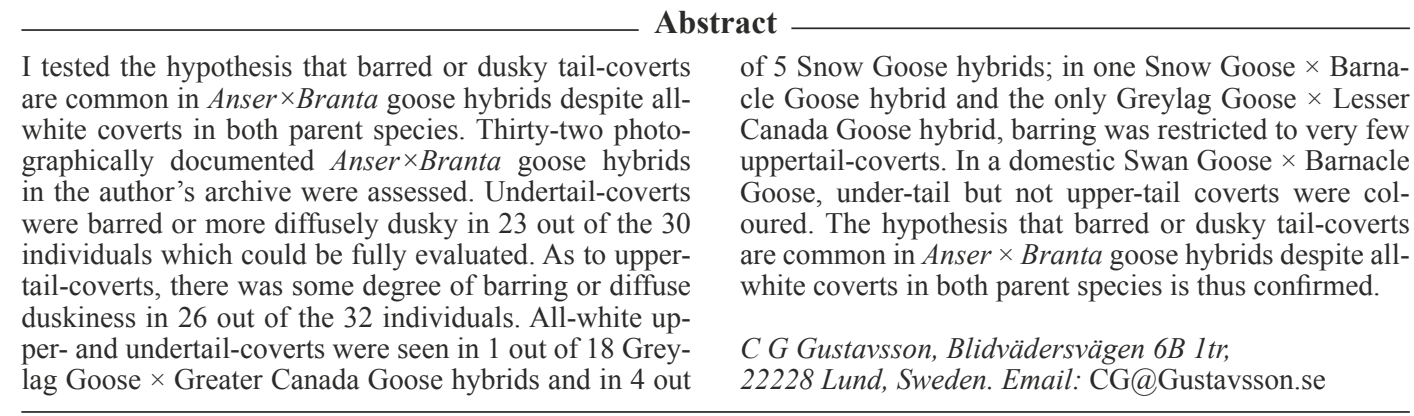

Received 16 March 2010, Accepted 6 August 2010, Editor: Å. Lindström

\section{Introduction}

Unexpected features may occur in bird hybrids. One example is the white area next to the bill which in my experience is commonly found in Greylag Goose Anser anser $\times$ Greater Canada Goose Branta canadensis hybrids, but less commonly in the pure parent species.

In web-discussions and at his own web site, Dave Appleton suggested that barred or dusky undertail coverts might be another such unexpected feature which often is seen in crosses between $A n$ ser and Branta goose species, despite purely white coverts in both parent species (Appleton (www)). The aim of this study was to evaluate that hypothesis in a set of photo-documented Anser $\times$ Branta goose hybrids. In addition, also uppertail coverts were studied.

\section{Material and methods}

All Anser $\times$ Branta goose hybrids in the author's photo archive were evaluated, except one which has a parent species with dark coverts (Emperor Goose Anser canagica). The number of studied individuals from different species combinations in relation to estimated total numbers in Sweden is shown in Table 1. In several species combinations, the numbers of studied individuals were thus in the magnitude of the whole Swedish populations. Individuals no. 20-24, 26, and 30-32 in Table 2 were presented in a previous article (Gustavsson 2009) and the five Greylag Goose Anser anser $\times$ Barnacle Goose Branta leucopsis hybrids no. 20-24 in Table 2 are individuals $\mathrm{A}-\mathrm{E}$ in that article.

There were 18 Greylag Goose $\times$ Greater Canada Goose hybrids, which on the one hand constituted a majority of the totally 32 subjects in this study, but on the other hand was only a fraction of the estimated totally 226 Greylag Goose $\times$ Greater Canada Goose hybrids in Sweden (Table 1). Eighteen individuals were however considered representative enough to get an idea about the prevalence of coloured tail coverts in that type of hybrid.

The study hypothesis was formulated in the spring 2008. The earlier collected part of the material was thus only reviewed retrospectively whereas later images were made also with this study in mind. Based on the impression that there would be both qualitative and quantitative differences between individuals, I categorised undertail covert colouration as barring or diffuse duskiness and 
when present I also quantified this on a scale from 0 (absent) to +++ (rich; Table 2). In some cases, it was not possible to achieve conclusive images. Such cases were classified as "?". For uppertail coverts, no differentiation between barring and diffuse duskiness was attempted.

\section{Results}

With respect to undertail coverts, the result was inconclusive for case 18 and partly inconclusive for case 16 (Table 2). Barred or more diffusely dusky undertail coverts were found in 23 out of the remaining 30 individuals and in all Anser $\times$ Branta goose hybrid combinations except the one bird where the Branta goose was a Lesser Canada Goose Branta hutchinsii and the five birds where the Anser parent was a Snow Goose Anser caerulescens. The only additional hybrid with all-white coverts was a Greylag Goose $\times$ Greater Canada Goose.

The degree and pattern of colouration differed both between and within different species combinations (Figures 1-5). The two most common hybrids were Greylag Goose $\times$ Greater Canada Goose and Greylag Goose $\times$ Barnacle Goose. In these, even the palest Barnacle Goose hybrid (Figure 3) had more extensive undertail covert colouration than the darkest Greater Canada Goose hybrid (Figure 1). Barring was the predominant colouration type when the Branta parent was a Greater Canada
Goose, whereas a more diffuse dusky colouration was more common when the Branta parent was a Barnacle Goose.

The material included three presumed $1^{\text {st }}$ Calendar year $\left(1^{\text {st }} \mathrm{Cy}\right)$ Greylag Goose $\times$ Greater Canada Goose hybrids (individuals 4-6) which were studied repeatedly from 17 August until 14 October 2009. Some minimal barring of undertail and uppertail coverts was seen already at the first observation and at least in one of them there was also conspicuous barring of tail feathers (Figure 6). Tail covert barring then progressively increased and at the last observation 14 October, all three had undisputable barring of both undertail and uppertail coverts (Table 2, Figures 7-8). Dusky uppertail coverts during the first summer were also seen in the five Greylag Goose × Barnacle Goose hybrids whereas image quality did not allow evaluation of undertail coverts. In the other species combinations, only adult birds were documented.

In some Greylag Goose $\times$ Greater Canada Goose hybrids, barring and spotting of tail-coverts seemed to be transiently lost in late summer. In individuals 1 and 2, barring had thus been evident 15 October 2008 (Figure 1) and 19 September 2008 respectively. On the next observations 17 August 2009 , only minimal barring (i.e. + ) according to the classification scale) could be seen and only when thoroughly searched for at close range (Figure 9). In the beginning of September, there was again a low degree barring (i.e. + ) which then increased to

Table 1. Number of hybrids in my study material $(\# \mathrm{H})$ compared to reported numbers (\#05) of different Anser $\times$ Branta Goose hybrids in Sweden 2005 according to Kampe-Persson \& Lerner (2007).

Antal hybrider i mitt studiematerial (\#H) jämfört med rapporterat antal individer (\#05) av olika Anser $\times$ Branta gåshybrider i Sverige 2005, enligt Kampe-Persson \& Lerner (2007).

\begin{tabular}{llrr}
\hline Branta & Anser & $\# \mathrm{H}$ & $\# 05$ \\
\hline Greater Canada Goose Kanadagås & White-fronted Goose Bläsgås & $0 *$ & 6 \\
& Greylag Goose Grågås & 18 & 226 \\
& Snow Goose Snögås & 1 & 2 \\
& Bar-headed Goose Stripgås & 0 & 1 \\
\hline Lesser Canada Goose Dvärgkanadagås & Greylag Goose Grågås & 1 & 0 \\
\hline Barnacle Goose Vitkindad gås & White-fronted Goose Bläsgås & $0 *$ & 1 \\
& Greylag Goose Grågås & 5 & 4 \\
& Snow Goose Snögås & $2 * *$ & $1-2$ \\
& Domesticated Swan Goose Knölgås & 1 & 0 \\
& Lesser White-fronted Goose Fjällgås & $0 *$ & 15 \\
& Bar-headed Goose Stripgås & 2 & 0 \\
\hline
\end{tabular}

$*=$ Not in the author's own material but pictures of individuals with coloured tail-coverts were found on Internet, see Discussion. Inte i författarens material men bilder av individer med färgade stjärttäckare funna på Internet, se diskussion.

** = Plus two in captivity. Plus två i fångenskap 
Table 2. The occurrence tail covert colouration in relation to parent species and date of observation. Abbreviations: $+++=$ rich,$++=$ moderate,$+=$ poor,$(+)=$ barely detectable, $0=$ absent, $?=$ images not conclusive, ${ }^{1}=$ 1 st $\mathrm{Cy},{ }^{2}=$ possible backcross with Branta canadensis, ${ }^{3}=$ captive bird

Fynd $i$ relation till föräldraarter och observationsdatum. Förkortningar: $+++=$ riklig, $++=$ måttlig, $+=$ svag, $(+)=$ knappt noterbar, $0=$ saknas, ? = bilder ej bedömbara, ${ }^{1}=1 \mathrm{k},{ }^{2}=$ möjlig återkorsning med Branta canadensis, ${ }^{3}=$ fägel i fängenskap

\begin{tabular}{|c|c|c|c|c|c|c|c|}
\hline $\begin{array}{l}\text { Ind. } \\
\text { no. }\end{array}$ & Anser & Branta & $\begin{array}{l}\text { Parentage } \\
\text { Föräldra } \\
\text { skap }\end{array}$ & $\begin{array}{r}\text { Date } \\
\text { Datum }\end{array}$ & $\begin{array}{l}\text { Under tail } \\
\text { coverts } \\
\text { barring } \\
\text { Strimmiga } \\
\text { undre } \\
\text { stjärttäckare }\end{array}$ & $\begin{array}{l}\text { Dusky under tail } \\
\text { coverts } \\
\text { Diffust mörka } \\
\text { undre } \\
\text { stjärttäckare }\end{array}$ & $\begin{array}{l}\text { Upper tail } \\
\text { coverts } \\
\text { colouration } \\
\text { Färgade } \\
\text { övre } \\
\text { stjärttäckare }\end{array}$ \\
\hline 1 & anser & canadensis & Presumed & 15 Oct 2008 & ++ & + & ++ \\
\hline 2 & anser & canadensis & Presumed & 18 Sep 2009 & + & ++ & + \\
\hline 3 & anser & canadensis & Presumed & 18 Sep 2009 & $(+)$ & 0 & $(+)$ \\
\hline $4^{1}$ & anser & canadensis & Presumed & 14 Oct 2009 & ++ & 0 & + \\
\hline $5^{1}$ & anser & canadensis & Presumed & 14 Oct 2009 & + & 0 & ++ \\
\hline $6^{1}$ & anser & canadensis & Presumed & 14 Oct 2009 & + & 0 & ++ \\
\hline 7 & anser & canadensis & Presumed & 25 Jul 2009 & ++ & $(+)$ & ++ \\
\hline 8 & anser & canadensis & Presumed & 25 Jul 2009 & ++ & ++ & + \\
\hline 9 & anser & canadensis & Presumed & 22 Aug 2009 & + & $(+)$ & + \\
\hline 10 & anser & canadensis & Presumed & $25 \mathrm{Jul} 2009$ & 0 & 0 & 0 \\
\hline 11 & anser & canadensis & Presumed & 12 Sep 2009 & ++ & + & ++ \\
\hline 12 & anser & canadensis & Presumed & 12 Sep 2009 & + & + & + \\
\hline 13 & anser & canadensis & Presumed & 12 Sep 2009 & + & 0 & + \\
\hline 14 & anser & canadensis & Presumed & 12 Sep 2009 & + & $?$ & + \\
\hline 15 & anser & canadensis & Presumed & 12 Sep 2009 & + & + & + \\
\hline 16 & anser & canadensis & Presumed $^{2}$ & 12 Sep 2009 & $?$ & 0 & + \\
\hline 17 & anser & canadensis & Presumed & 12 Sep 2009 & + & $?$ & + \\
\hline 18 & anser & canadensis & Presumed & 12 Sep 2009 & $?$ & $?$ & + \\
\hline 19 & anser & hutchinsii & Presumed & 12 Sep 2009 & 0 & 0 & $(+)$ \\
\hline 20 & anser & leucopsis & Proven & 5 Jun 2007 & ++ & ++ & ++ \\
\hline 21 & anser & leucopsis & Proven & 10 Jun 2009 & ++ & ++ & + \\
\hline 22 & anser & leucopsis & Proven & 28 Jun 2008 & ++ & + & ++ \\
\hline 23 & anser & leucopsis & Proven & 28 Jun 2008 & ? & +++ & $0 /++$ \\
\hline 24 & anser & leucopsis & Proven & 2 Oct 2009 & ++ & +++ & $+/++$ \\
\hline 25 & caerulescens & canadensis & Presumed & 10 Oct 2006 & 0 & 0 & 0 \\
\hline 26 & caerulescens & leucopsis & Proven & $11 \mathrm{Jul} 2006$ & 0 & 0 & + \\
\hline 27 & caerulescens & leucopsis & Presumed & 26 Apr 2003 & 0 & 0 & 0 \\
\hline $28^{3}$ & caerulescens & leucopsis & Presumed & 5 Mar 2010 & 0 & 0 & 0 \\
\hline $29^{3}$ & caerulescens & leucopsis & Presumed & 5 Mar 2010 & 0 & 0 & 0 \\
\hline 30 & cygnoides & leucopsis & Presumed & 8 Jul 2006 & 0 & ++ & 0 \\
\hline 31 & indicus & leucopsis & Presumed & Feb 2004 & ++ & ? & ++ \\
\hline 32 & indicus & leucopsis & Presumed & 12 Jul 2008 & 0 & ++ & + \\
\hline
\end{tabular}

be fully developed again when both birds were last seen 14 October 2009. In individual 8 (Table 2), barring had been obvious 25 July 2009 but was reduced though still well visible on the next observation 22 August 2009. In yet another bird, individual 3 , no barring was seen until the last observation 18 September 2009 when there was a very faint and thin barring which was visible only at extremely close range (Figure 2).
As to uppertail coverts, these were found to be coloured in 26 out of the 32 hybrids. This number is slightly higher than for undertail coverts. The difference was due to the absence of inconclusive results and to minimal barring in two cases with all-white undertail coverts; one of the four Snow Goose $\times$ Barnacle Goose hybrids and the only Greylag Goose $\times$ Lesser Canada Goose. On the other hand, only white uppertail coverts could be 

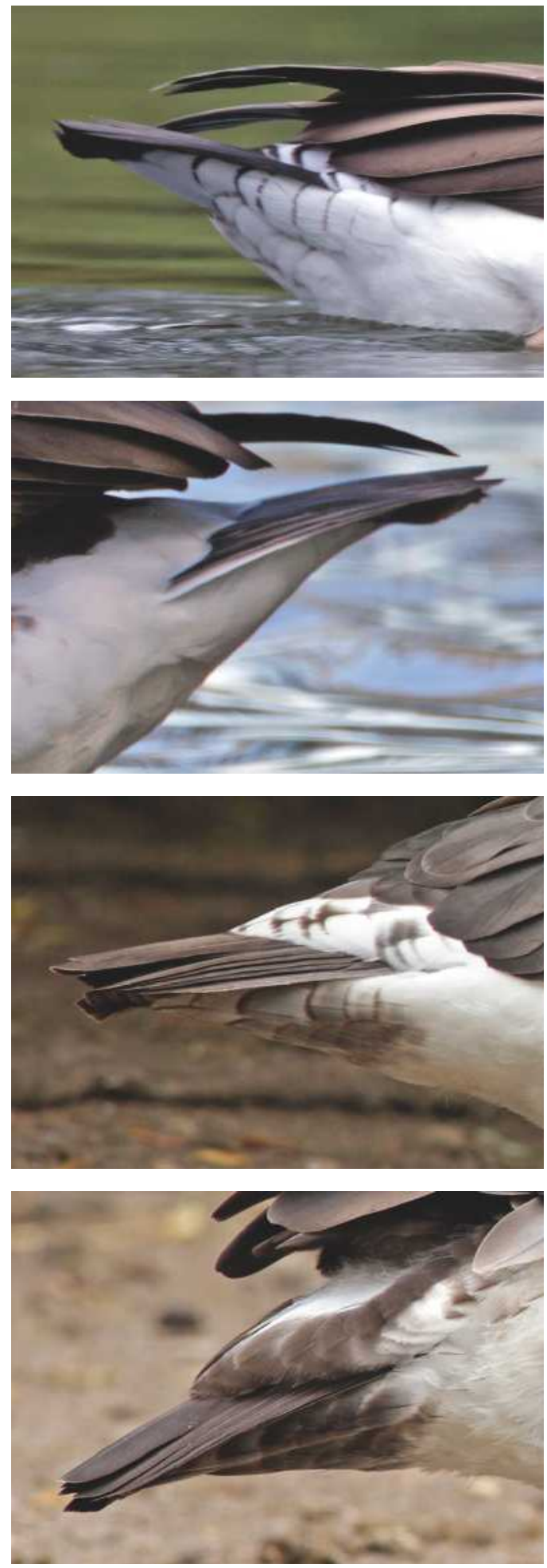

Figure 1. Individual 1. This is one of the Greylag Goose $\mathrm{x}$ Canada Goose hybrids with the richest barring of both undertail- and uppertail-coverts, classified as ++. 15 October 2008.

Individ 1. Detta är en av grågås x kanadagås hybriderna med den mest uttalade tvärstimmigheten på både de undre och övre stjärttäckarna, klassificerade som ++. 15 oktober 2008.

Figure 2. Individual 3. This was the only occasion when some faint barring of the tail coverts could be ascertained in this bird. 18 September 2009.

Individ 3. Detta var det enda tillfälle då en svag strimmighet på stjärttäckarna kunde säkerställas på denna fågel. 18 september 2009.

Figure 3. Individual 22. This is the palest of the five Greylag Goose x Barnacle Goose hybrids but it is still darker than the darkest Greylag Goose x Canada Goose hybrids. 28 June 2008.

Individ 22. Detta är den blekaste av de fem grågås $x$ vitkindad gås hybriderna men den är ändå mörkare än den mörkaste av grågås x kanadagås hybriderna. 28 juni 2008.

Figure 4. Individual 23. This is the darkest of the Greylag Goose x Barnacle Goose hybrids, with diffuse greyishbrown colouration of undertail- and uppertail-coverts. 28 June 2008.

Individ 23. Detta är den mörkaste av grågås $x$ vitkindad gås hybriderna, med diffus gråbrun mörkfärgning av undre och övre stjärttäckare. 28 juni 2008. 
Figure 5. Individual 24. This Greylag Goose x Barnacle Goose hybrid has a number of colouration varieties with diffuse duskiness of undertail-coverts but also greyish black barring, pale barring and brownish areas. 2 October 2009. Individ 24. Denna grågås $x$ vitkindad gås hybrid har flera färgvarianter, med diffust mörka undre stjärttäckare men också gråsvart strimmighet, ljus strimmighet och brunaktiga områden. 2 oktober 2009.

Figure 6. Presumably individual 4. On the first observation 17 August 2009, there was very faint barring of a few undertail-coverts in this 1st Cy Greylag Goose x Canada Goose hybrid but several tail feathers were conspicuously barred. Antagligen individ 4. Vid första observationstillfället 17 augusti 2009 fanns det mycket svag strimmighet på några undre stjärttäckare på denna $1 k$ grågås x kanadagås hybrid men flera stjärtfjädrar var iögonenfallande tvärstrimmiga.

Figure 7. Individual 4. On the latest observation 14 October 2009, this was the 1st Cy Greylag Goose x Canada Goose hybrid with the richest barring of undertail-coverts.

Individ 4. Vid den senaste observationen 14 oktober 2009 var detta den $1 \mathrm{k}$ grågås $x$ kanadagås hybrid som hade mest tvärstrimmighet.

Figure 8. Individual 6. On the latest observation 14 October 2009, this was the 1st Cy Greylag Goose x Canada Goose hybrid with the poorest barring.

Individ 6. Vid den senaste observationen 14 oktober 2009 var detta den $1 \mathrm{k}$ grågås $x$ kanadagås hybrid som hade minst tvärstrimmighet.
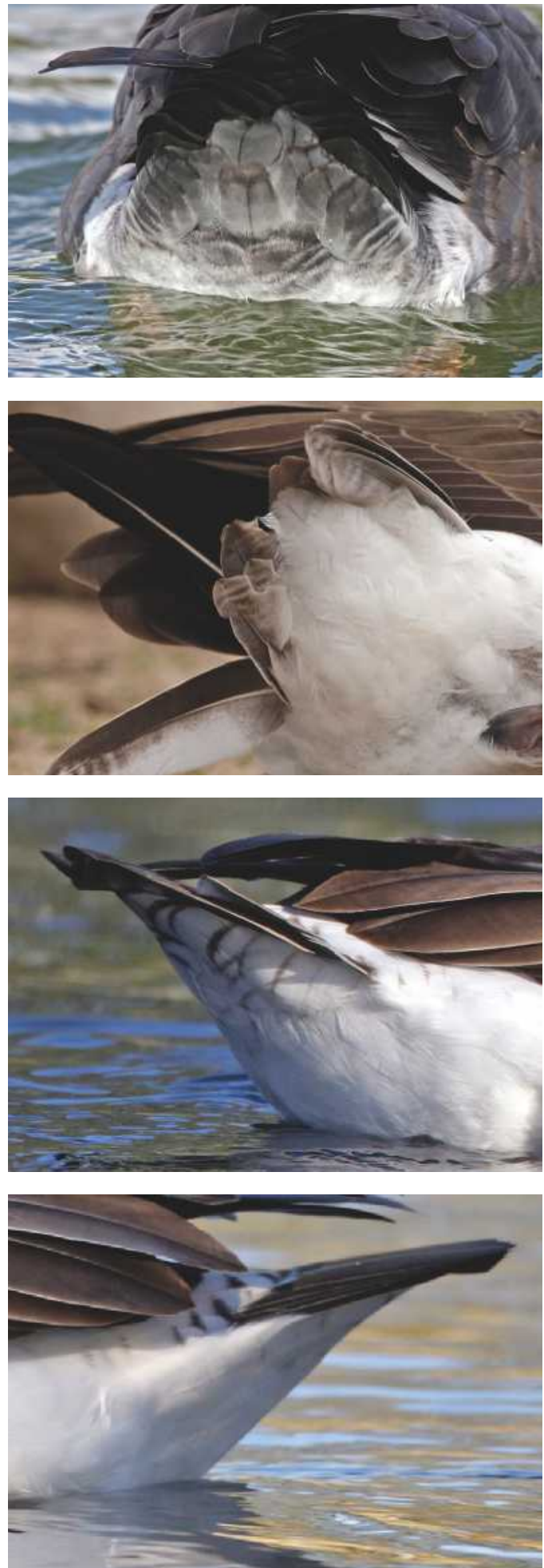

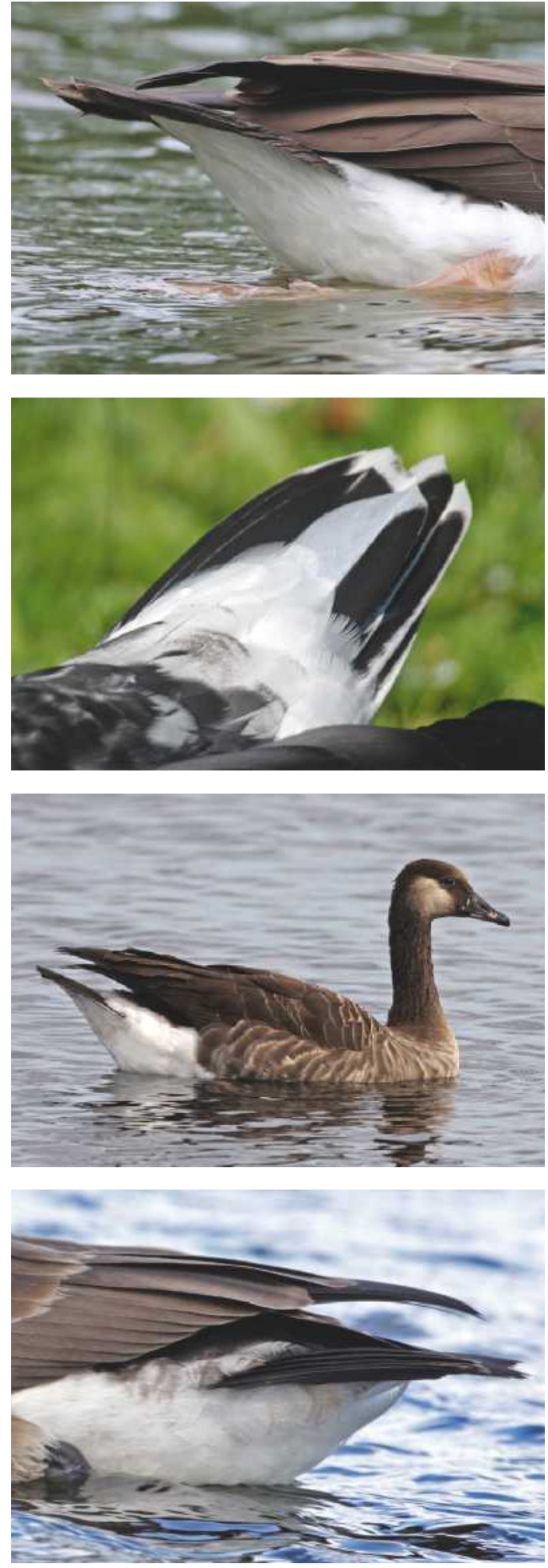

Figure 9. Please compare to Figure 1 - this is also individual 1. At the earliest observation date 17 August 2009, only minimal barring just below the flight feathers could be seen. Jämför med Figur 1 - detta är också individ 1. Vid tidigaste observationsdatum 17 augusti 2009 sågs bara minimal tvärstrimmighet just nedom vingpennorna.

Figure 10. Individual 26. Only three out of several hundred pictures from various angles showed a few barred feathers in this Snow Goose x Barnacle Goose hybrid. 5 September 2007.

Individ 26. Bara tre av flera hundra bilder från olika vinklar visade ett fåtal strimmiga fjädrar på denna snögås $x$ vitkindad gås hybrid. 5 september 2007.

Figure 11. Individual 16. This bird was classified as Greylag Goose x Canada Goose but differs from the other hybrids of that species combination. Backcross with Canada Goose? 12 September 2009.

Individ 16. Denna fågel klassificerades som grågås $x$ kanadagås men skiljer sig från övriga individer av den artkombinationen. Aterkorsning med kanadagås? 12 september 2009.

Figure 12. Greyish brown barring of undertail- and uppertail-coverts was also seen in several birds which were considered to be 1st Cy pure Canada Geese but not in any adult bird. 22 August 2009.

Gråbrun tvärstrimmighet på undre och övre stjärttäckare såg också på flera fåglar som uppfattades vara $1 \mathrm{k}$ artrena kanadagäss men inte hos någon adult fågel. 22 augusti 2009. 
Figure 13. Partly dusky uppertail-coverts in a 1st Cy Greylag Goose. 17 July 2010.

Delvis gråa övre stjärttäckare på en $1 k$ grågås. 17 juli 2010.

seen in the domesticated Swan Goose $\times$ Barnacle Goose hybrid which had dusky undertail coverts.

\section{Discussion}

This study confirms the hypothesis that barred and spotted undertail coverts are common in Anser $\times$ Branta goose hybrids despite all-white coverts in both parent species. This applies to hybrids of two out of the three studied Branta species, Barnacle Goose and Greater Canada Goose, and to all Anser species except Snow Goose. The Greylag Goose $\times$ Lesser Canada Goose hybrid and the five Snow Goose hybrids had all-white undertail coverts. In addition, not only undertail but also uppertail coverts were barred or spotted in several individuals of several species combinations, also including one of the four Snow Goose $\times$ Barnacle Goose hybrids (Figure 10) and the Greylag Goose $\times$ Lesser Canada Goose hybrid.

\section{Reasons for negative and inconclusive results}

In 3 out of totally 18 presumed Greylag Goose $\times$ Greater Canada Goose hybrids, no barring of undertail coverts could be detected (individuals 10, 16, and 18). This may have several causes:

1. The bird is indeed a F1 hybrid with all-white tail coverts.

2. The observation was made at a disadvantageous time in a bird in which repeat observation at another time might have provided a different result. In individuals 1 and 2, barring was thus evidently reduced to be barely detectable for a short period during moulting in late summer. In individual 3, it was not until the last of several observations that a very faint and thin barring of undertail coverts could be registered. Individual 10 was ob-

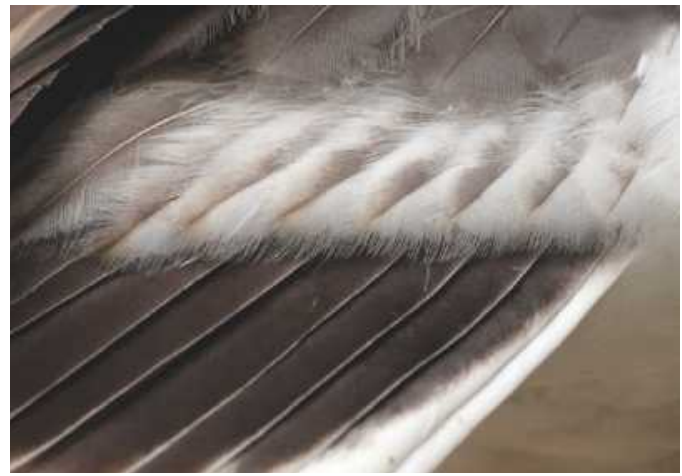

served only once, 25 July 2009 . It is thus uncertain whether its all-white coverts could be due to such a temporal phenomenon, or if the bird constantly carried all-white coverts.

3. Methodological problems may lead to falsely negative or inconclusive results. Barring may be present but so faint and thin that it can be seen only at short range and under optimal conditions (e.g. individual 3). Evaluations were made from photographs of wild birds using focal lengths of 400-1600 $\mathrm{mm}$ and detail enlargements. Even so, it was in some cases difficult to come close enough to achieve sufficient image quality. Thin barring similar to that in individual 3 could thus probably not have been visible in individual 16. More marked colouration should however not have gone unnoticed. That particular case was thus regarded as partly inconclusive. Among other circumstances which may have interfered with registration quality are reflexes from the water or otherwise disadvantageous light conditions, unsuitable body positions of the bird, and disturbing vegetation. In individual 18 , only a small part of the undertail coverts were visible and no conclusion could be drawn.

4. The bird may not be a F1 hybrid but a backcross. This possibility cannot be excluded in individual 16 (Figure 11), which may be a (Greylag Goose $\times$ Greater Canada Goose) $\times$ Greater Canada Goose. Such a backcross should be expected to be more similar to pure Greater Canada Geese, and could maybe for that reason have all-white tail coverts.

\section{Different colour pattern in Barnacle Goose and Greater Canada Goose hybrids}

Greylag Goose hybrids had a more diffuse dusky type of tail covert colouration in crosses with Bar- 
nacle Goose and a more barred type in crosses with Greater Canada Goose. All five Barnacle Goose hybrids were siblings and it can thus not be ruled out that their colouration pattern is a heritage from a single genetically extreme parent individual rather than representative for the species combination as such. However, the more diffuse type of duskiness was seen also in other Barnacle Goose crosses such as Swan Goose $\times$ Barnacle Goose and Bar-headed Goose $\times$ Barnacle Goose. This favours the alternative that the different colour patterns are indeed correlated to the parent species.

\section{Missing species combinations}

One important limitation of the study was that some of the species combinations, which according to Kampe-Persson \& Lerner (2007) were reported to occur in Sweden 2005 (Table 1), were missing in the study material, most notably the not too uncommon Lesser White-fronted Goose Anser erythropus $\times$ Barnacle Goose Branta leucopsis hybrid. The other missing hybrids were White-fronted Goose Anser albifrons $\times$ Greater Canada Goose, Bar-headed Goose Anser indicus $\times$ Greater Canada Goose, and White-fronted Goose $\times$ Barnacle Goose. However, a web search found coloured tail coverts also in Lesser White-fronted Goose $\times$ Barnacle Goose (Lehto (www)), White-fronted Goose $\times$ Greater Canada Goose (Schmoker (www)) and White-fronted Goose $\times$ Barnacle Goose hybrids (Smith (www)). These crosses are marked $*$ in Table 1. Out of the species which were reported to occur in Sweden 2005, it was thus only Bar-headed Goose $\times$ Greater Canada Goose which I could not locate any picture of. In addition to the species combinations reported by Kampe-Persson \& Lerner (2007), coloured tail coverts were also found in pictures of domesticated Swan Goose Anser cygnoides $\times$ Greater Canada Goose Branta canadensis (Randler 2001, Sweet (www)). Accordingly it seems as if coloured tail coverts are common also in the Anser $\times$ Branta species combinations which were not included in the study material.

\section{Are coloured tail-coverts a preserved juvenile feature?}

In late summer, several individuals which were all thought to be $1^{\text {st }} \mathrm{Cy}$ pure Canada Geese had barred undertail and uppertail coverts (Figure 12). This was not seen in adult birds. Partly grey colour of uppertail-coverts but with a more even distribution was also seen in all five closely examined $1^{\text {st }} \mathrm{Cy}$
Greylag Geese (Figure 13) and like in the Greylag Goose $\times$ Barnacle Goose hybrids (e.g. in Figure 4) it was the median half of the feathers that were darkest. My speculative explanation for coloured tail coverts in the hybrids is thus that they are modified juvenile features which are not only preserved in adulthood but often also enhanced in the hybrids.

\section{Acknowledgements}

The author is indebted to Henry Lehto for allowing his pictures to be compared to the author's and for constructive suggestions, and to Dave Appleton and Jörn Lehmhus for enlightening information on the original ideas about dusky and barred undertailcoverts.

\section{References}

Appleton, D. http:/www.flickr.com/groups/hybridbirds/ discuss/72157601783757808/

Appleton, D. http:/www.flickr.com/groups/hybridbirds/ discuss/72157601880379256/

Appleton, D. http://www.gobirding.eu/Photos/HybridGeese. php\#Canada $\times$ Greylag

Gustavsson, C.G. 2009. Images of Barnacle Goose Branta leucopsis hybrids - a photo documentation of some crosses with different Anser species. Ornis Svecica 19: 19-31.

Lehto, H. http://www.flickr.com/photos/33236701@ N07/3816606759/sizes/o/

Randler, C. 2001. Field identification of hybrid waterfowlGeese. Alula 7: 42-48.

Schmoker, B. http://www.schmoker.org/BirdPics/Photos/ Waterfowl/GWFGxCANG2.jpg

Smith, G. http://www.flickr.com/photos/gjs1/2278934279/

Sweet, W. http://www.flickr.com/photos/22560927@, N04/4073934158/sizes/1/

\section{Sammanfattning}

Strimmiga och mörkfläckiga undre och övre stjärttäckare verkar vara vanliga hos hybrider mellan Anser och Branta gäss, även i de fall då båda föräldraarterna har helvita täckare. Fenomenet undersöktes på 32 dokumenterade Anser $\times$ Branta hybrider i författarens bildarkiv. Tabell 1 visar antalet studerade individer i de olika artkombinationerna i relation till det av Kampe-Persson och Lerner (2007) uppskattade totala antalet exemplar i Sverige. I flera av artkombinationerna är alltså antalet studerade fåglar jämförbart med hela den svenska populationen. Vad gäller grågås $\times$ kanadagås utgör 18 studerade fåglar bara en liten del av det uppskattade totalantalet 226 , men bedömdes ändå vara 
ett tillräckligt representativt antal. Utöver de av Kampe-Persson och Lerner (2007) rapporterade artkombinationerna ingick ytterligare tre kombinationer i materialet: grågås $\times$ dvärgkanadagås, knölgås $\times$ vitkindad gås och stripgås $\times$ vitkindad gås. Bland de artkombinationer som saknas i materialet märks framför allt fjällgås $\times$ vitkindad gås.

Tabell 2 visar de studerade individerna. I ett fall kunde de undre stjärttäckarna inte bedömas, och i ett annat fall kunde bara mera uttalad mörkfärgning uteslutas (individerna 18 och 16). Av de resterande 30 individerna hade 23 strimmiga eller mera diffust mörkfärgade undre stjärttäckare. Helvita undre stjärttäckare såg hos alla 5 snögåshybriderna, den enda hybriden grågås $\times$ dvärgkanadagås, samt $1 \mathrm{av}$ 18 hybrider grågås $\times$ kanadagås. Vid jämförelse mellan grågås $\times$ kanadagås och grågås $\times$ vitkindad gås hade de förstnämnda mindre av diffus mörkfärgning men lika mycket eller mer av tvärstrimmighet på de undre stjärttäckarna. Även de övre stjärttäckarna bedömdes och där var bildkvalitet och projektioner tillräckliga hos samtliga. Någon grad av mörkfärgning av övre stjärttäckare såg hos 26 av 32 individer. Vita övre stjärttäckare såg hos
4 av 5 snögåshybrider, hos den hybrid grågås $\times$ kanadagås som också hade vita undre täckare, samt hos den enda hybriden knölgås $\times$ vitkindad gås. Den femte snögåshybriden och hybriden grågås $\times$ dvärgkanadagås hade endast enstaka strimmiga övre täckare.

Studien bekräftade således hypotesen att strimmiga eller diffust mörka undre stjärttäckare är vanligt förekommande hos Anser $\times$ Branta gåshybrider, även om båda föräldraarterna har helvita täckare. Även de övre stjärttäckarna är ofta mörkfärgade. De fem hybriderna med snögås utgjorde ett undantag, med vita undre täckare hos alla fem och vita övre täckare hos fyra. Bedömning av fotografier från internet tyder på att färgade stjärttäckare förekommer även vid flera artkombinationer som inte ingick i materialet; dessa har i Tabell 1 markerats med *. Strimmiga täckare sågs också hos en del 1k kanadagäss (Figur 12) men inte hos adulta kanadagäss. Samtliga fem noga undersökta $1 \mathrm{k}$ grågäss hade delvis gråfärgade täckare (Figur 13). Kanske är de mörkfärgade täckarna hos hybriderna någon form av juvenil karaktär som behålls av adulter? 